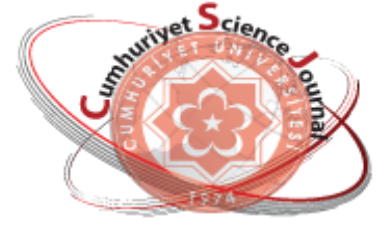

e-ISSN: $2587-246 X$

ISSN: $2587-2680$

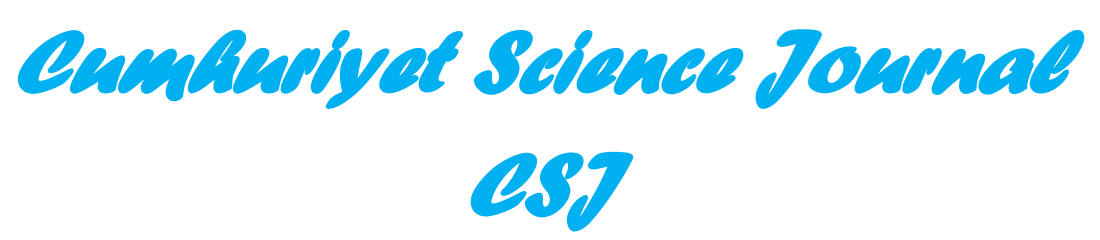

Cumhuriyet Sci. J., Vol.38-3 (2017) 588-593

\title{
Investigation of Structural, Optical and Photovoltaic Properties of Sb2S3 Thin Films
}

\author{
Sabit HOROZ ${ }^{1 *}$, Hüsnü KOC ${ }^{1}$ Ömer SAHIN ${ }^{2}$ \\ ${ }^{1}$ Siirt University, Faculty of Art and Sciences, Department of Physics, 56100, Siirt, TURKEY
}

${ }^{2}$ Siirt University, Faculty of Engineering and Architecture, Department of Chemical Engineering, 56100, Siirt, TURKEY,

http://dx.doi.org/10.17776/csj.340520

\begin{abstract}
Sb}_{2} \mathrm{~S}_{3}$ thin films were prepared on amorphous glass substrates by chemical bath deposition (CBD) at room temperature. The $\mathrm{Sb}_{2} \mathrm{~S}_{3}$ thin films were characterized by x-ray diffraction (XRD), Raman spectroscopy, scanning electron microscopy (SEM) and UV-Vis spectroscopy. The XRD revealed that the as deposited $\mathrm{Sb}_{2} \mathrm{~S}_{3}$ thin film has a different structure compared to annealed $\mathrm{Sb}_{2} \mathrm{~S}_{3}$ thin film. As deposited $\mathrm{Sb}_{2} \mathrm{~S}_{3}$ thin film showed amorphous structures while the $\mathrm{Sb}_{2} \mathrm{~S}_{3}$ thin film became polycrystalline after annealing at $350{ }^{\circ} \mathrm{C}$ for $1 \mathrm{~h}$ under $\mathrm{N}_{2}$. The band gaps of the $\mathrm{Sb}_{2} \mathrm{~S}_{3}$ thin films were compared using UV-Vis spectroscopy. The spectral response of the $\mathrm{Sb}_{2} \mathrm{~S}_{3}$ thin film enhanced after the annealing process. The $\mathrm{Sb}_{2} \mathrm{~S}_{3}$ thin films were subsequently used to make semiconductor-sensitized $\mathrm{TiO}_{2}$ nanowire (NW) solar cells. The performances of the solar cells, with the short circuit current density and open circuit voltage, were investigated. Based on the optical and photovoltaic measurements, we consider that annealed $\mathrm{Sb}_{2} \mathrm{~S}_{3}$ thin films can be promising materials for developing solar cell technologies.
\end{abstract}

Keywords: $\mathrm{Sb}_{2} \mathrm{~S}_{3}$ thin films, chemical bath deposition, semiconductor -sensitized solar cells

\section{INTRODUCTION}

Recently, much attention has been paid to the preparation and characterization of the group V-VI compounds due to their novel optical properties. The one of the most important metal chalcogenides group $\mathrm{A}_{2}{ }^{\mathrm{V}} \mathrm{B}_{3}{ }^{\mathrm{VI}}$ is $\mathrm{Sb}_{2} \mathrm{~S}_{3}$ with direct bandgap of $\sim$ 1.78- 2.5 e V [1-5], has widely used as an important material in many different technological areas such as microwave devices, solar cells, various optoelectronics devices, and IR sensors because of their physical and chemical properties [6-15].

From the application view, sensitized solar cells with inorganic semiconductors are promising candidates for developing low-cost and high performance photovoltaic devices. The one of the most important part of structure of semiconductor -sensitized solar cells is sensitizer. The $\mathrm{Sb}_{2} \mathrm{~S}_{3}$ thin films can be used as sensitizers due to their remarkable optical and electrical properties. For instance, $\mathrm{Li}$ et al.[16] investigated annealing effect on $\mathrm{Sb}_{2} \mathrm{~S}_{3}-\mathrm{TiO}_{2}$ nanostructures for solar cells application in 2013. They concluded that the photovoltaic conversion efficiency for this structure increase from $0,46 \%$ up to $1,47 \%$ as a consequence of the annealing treatment.

Thin film or powders can be synthesized by several well-known methods. The CBD which is a simple and inexpensive method is considered as one of the most appropriate method [17]. In comparison other methods which require long time and extreme laboratory conditions, the thin films can be synthesized with simple laboratory equipments and within a few hours using the CBD method. 
In our present study, the synthesis of $\mathrm{Sb}_{2} \mathrm{~S}_{3}$ thin films were prepared on amorphous glass substrates by chemical bath deposition (CBD) at room temperature, are reported. Structural, morphological, optical and photovoltaic properties of as-deposited and annealed $\mathrm{Sb}_{2} \mathrm{~S}_{3}$ thin films have been investigated. The effect of annealing temperature on the optical and photovoltaic properties is discussed.

\section{EXPERIMENTAL DETAILS}

To synthesize $\mathrm{Sb}_{2} \mathrm{~S}_{3}$ thin films at room temperature, commercial antimony chloride $\left(\mathrm{SbCl}_{3}\right)$ and sodium thiosulfate $\left(\mathrm{Na}_{2} \mathrm{~S}_{2} \mathrm{O}_{3} .5 \mathrm{H}_{2} \mathrm{O}\right)$ were used without any further purification. In a typical CBD method, $650 \mathrm{mg}$ of $\mathrm{SbCl}_{3}$ was dissolved in $10 \mathrm{ml}$ of acetone in a clean beaker. 25 $\mathrm{mL}$ of $1 \mathrm{M}$ aqueous solution of sodium thiosulfate was added into a solution containing $\mathrm{SbCl}_{3}$. The total volume of mixture was made $100 \mathrm{~mL}$ by addition appropriate amount of deionized water. After obtaining a homogeneous mixture, $25 \mathrm{ml}$ of the $\mathrm{Sb}_{2} \mathrm{~S}_{3}$ solution was transferred to another clean beaker, then two glass microscope slides which were cleaned well with diluted hydrochloric acid, washed by double distilled water and dried, were vertically left into $\mathrm{Sb}_{2} \mathrm{~S}_{3}$ solution for 45 minutes. Afterwards, the glass substrates were removed from the chemical bath, washed well with deionized water and dried in air. One of the glass substrates was annealed at $350{ }^{\circ} \mathrm{C}$ for $1 \mathrm{~h}$ under $\mathrm{N}_{2}$.

X-ray diffraction (XRD) on a Rigaku x-ray diffractometer with $\mathrm{Cu} \mathrm{K} \mathrm{K}_{\alpha}(\lambda=154,059 \mathrm{pm})$ radiation, Raman spectroscopy (DeltaNu ExamineR), and scanning electron microscopy (SEM) (JEOL JSM 5800) were used to analyze structural and morphological properties of $\mathrm{Sb}_{2} \mathrm{~S}_{3}$ thin films, respectively. A Perkin Elmer Lamba 2 spectrometer was used to record UV-Vis absorption spectra to analyze optical properties of $\mathrm{Sb}_{2} \mathrm{~S}_{3}$ thin films.

The performances of fabricated $\mathrm{Sb}_{2} \mathrm{~S}_{3}$ devices were tested under a light intensity of $100 \mathrm{~mW} / \mathrm{cm}^{2}$ from a $150 \mathrm{~W}$ Xenon arc lamp. For current density $(\mathrm{J})$ voltage $(\mathrm{V})$ measurements, fluorine doped tin oxide (FTO, $13 \Omega . \mathrm{sq}^{-2}$ ) conductive glass substrates were used as the photo electrodes. The $\mathrm{TiO}_{2}$ nanowires (NWs) were coated on the FTO substrates using the doctor blade method, then sintered at $450{ }^{\circ} \mathrm{C}$ for certain time. $\mathrm{Sb}_{2} \mathrm{~S}_{3}$ thin films were grown on the $\mathrm{TiO}_{2} \mathrm{NWs}$ coated on the FTO substrates by CBD method at room temperature. One of the $\mathrm{Sb}_{2} \mathrm{~S}_{3}$ thin films grown on the $\mathrm{TiO}_{2} \mathrm{NWs}$ coated on the FTO substrates was annealed at 350 ${ }^{0} \mathrm{C}$ for $1 \mathrm{~h}$ under $\mathrm{N}_{2}$. Then, the obtained annealed and as-deposited $\mathrm{Sb}_{2} \mathrm{~S}_{3}$ films grown on the $\mathrm{TiO}_{2}$ NWs coated on the FTO substrates were secured against $\mathrm{Cu}_{2} \mathrm{~S}$ counter electrode containing a polysulfide electrolyte. Dai et al. [18] indicated the preparation of were $\mathrm{Cu}_{2} \mathrm{~S}$ counter electrode and polysulfide electrolyte.

\section{RESULTS and DISCUSSIONS}

Figure 1 demonstrates the XRD patterns of asdeposited and annealed $\mathrm{Sb}_{2} \mathrm{~S}_{3}$ thin films deposited onto glass substrates by chemical bath deposition at room temperature. It can be clearly seen that the $\mathrm{Sb}_{2} \mathrm{~S}_{3}$ thin film was obtained with a good crystalline structure when it was annealed at $350{ }^{\circ} \mathrm{C}$ for $1 \mathrm{~h}$ while as- deposited $\mathrm{Sb}_{2} \mathrm{~S}_{3}$ thin film showed amorphous structure. All diffraction peaks of annealed thin film prepared at room temperature can be well indexed as the orthorhombic phase structure of $\mathrm{Sb}_{2} \mathrm{~S}_{3}$, which is consistent with the standard card (ICDD 00-001-0538).

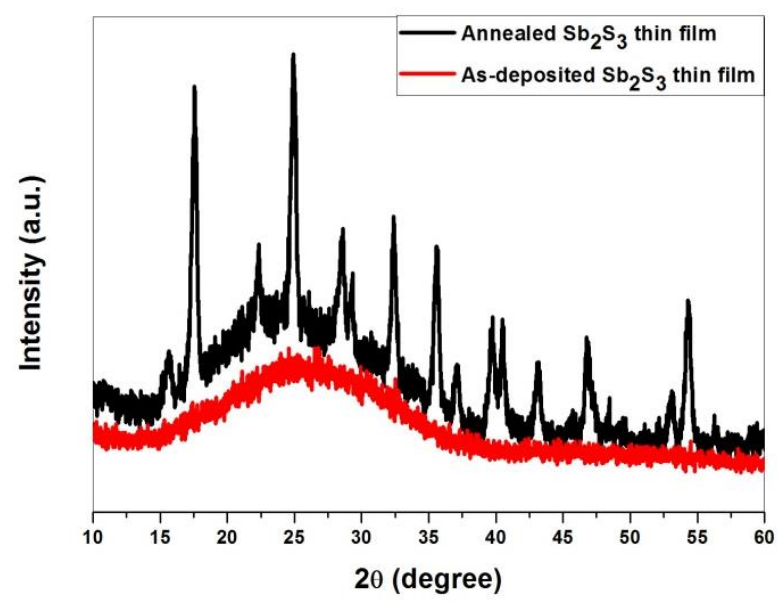

Figure 1. The XRD patterns of as- deposited $\mathrm{Sb}_{2} \mathrm{~S}_{3}$ and annealed $\mathrm{Sb}_{2} \mathrm{~S}_{3}$ thin films.

The diffraction peaks of annealed $\mathrm{Sb}_{2} \mathrm{~S}_{3}$ thin film prepared at room temperature were used to 
calculate d-values using by Bragg's law as given in Equation 1:

$$
\mathrm{d}=\lambda / 2 * \sin \theta
$$

Where, $d$ is the lattice spacing, $\lambda$ is wavelength of the used $\mathrm{x}$-ray, and $\theta$ is the Bragg's diffraction angle. Calculated $d$ values were compared with standard d values, which are revealed in Table 1.

Table 1. Comparison of the standard " $\mathrm{d}$ " values and calculated "d" values of annealed $\mathrm{Sb}_{2} \mathrm{~S}_{3}$ thin film.

\begin{tabular}{cccc}
$\begin{array}{c}2 \boldsymbol{\theta} \\
\text { (degree) }\end{array}$ & $\begin{array}{c}\text { Calculated"d" } \\
\text { values }(\mathbf{\AA})\end{array}$ & $\begin{array}{c}\text { Standard "d" } \\
\text { Values }(\mathbf{\AA})\end{array}$ & hkl \\
\hline 17.58 & 5.040 & 5.040 & $(1,2,0)$ \\
22.70 & 3.920 & 3.917 & $(2,2,0)$ \\
24.94 & 3.567 & 3.570 & $(1,3,0)$ \\
28.63 & 3.116 & 3.117 & $(2,1,1)$ \\
32.40 & 2.761 & 2.763 & $(2,2,1)$ \\
35.58 & 2.521 & 2.523 & $(4,2,0)$ \\
39.66 & 2.271 & 2.272 & $(0,4,1)$ \\
43.19 & 2.093 & 2.094 & $(5,2,0)$ \\
46.74 & 1.942 & 1.943 & $(5,0,1)$ \\
53.13 & 1.723 & 1.724 & $(5,3,1)$ \\
54.32 & 1.687 & 1.689 & $(3,60)$ \\
\hline
\end{tabular}

There is a good agreement between both of $d$ values. Based on the Table 1, the $\mathrm{Sb}_{2} \mathrm{~S}_{3}$ thin film was obtained as desired after it was annealed at 350 ${ }^{0} \mathrm{C}$ for $1 \mathrm{~h}$ under $\mathrm{N}_{2}$.

The SEM image of annealed $\mathrm{Sb}_{2} \mathrm{~S}_{3}$ thin film is shown in Figure 2a reveals that the shape of the grains is spherical. After annealing treatment, $\mathrm{Sb}_{2} \mathrm{~S}_{3}$ thin film shows more uniform and higher grain size while the shape of the grain size of as deposited $\mathrm{Sb}_{2} \mathrm{~S}_{3}$, thin film prepared by Krishan et al. [15], is not clear. This is in a good agreement with our result obtained from XRD measurement.

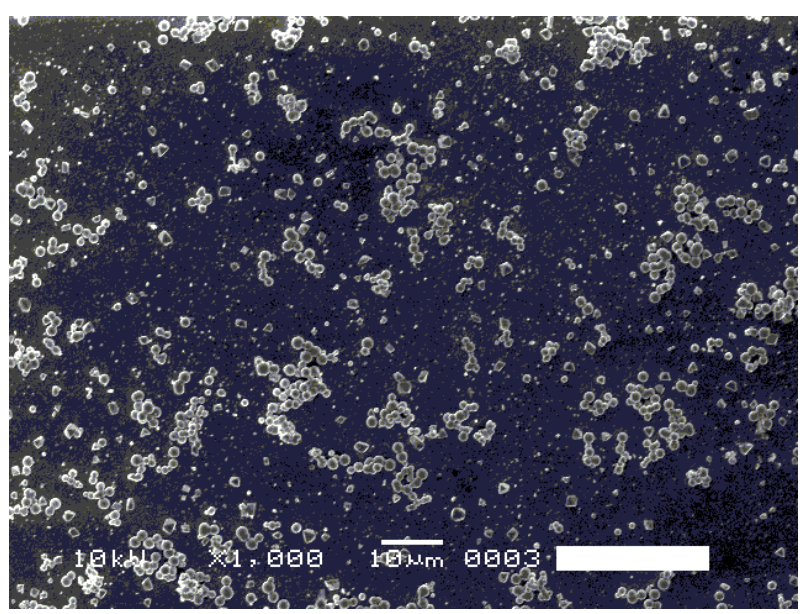

Figure 2a. SEM image of $\mathrm{Sb}_{2} \mathrm{~S}_{3}$ thin film annealed at $350{ }^{\circ} \mathrm{C}$ for $1 \mathrm{~h}$ under $\mathrm{N}_{2}$.

The energy dispersive $\mathrm{x}$-ray (EDX) spectrum was used to confirm the elemental compositions of the $\mathrm{Sb}_{2} \mathrm{~S}_{3}$ thin film. The peaks obtained from the EDX spectrum (shown in Figure 2b) are associated with $\mathrm{S}$ and $\mathrm{Sb}$. This result is consistent with observation of Pan et al. [19]. They concluded that the peak located in low energy region is assigned to $\mathrm{S} \mathrm{K}_{\alpha}$ while three peaks located in higher energy regions are assigned to $\mathrm{Sb} \mathrm{L}_{\alpha}$. Based on the EDX spectrum, the molar ratio of $\mathrm{Sb} / \mathrm{S}$ found using the peak areas, $37.51 / 62.46$, which is close to $2 / 3$.

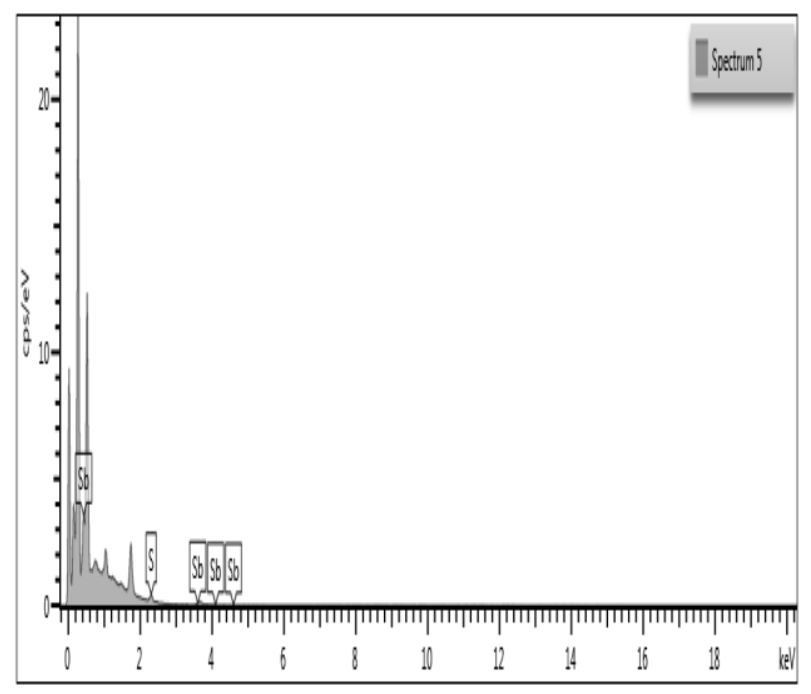

Figure 2b. EDX spectrum of $\mathrm{Sb}_{2} \mathrm{~S}_{3}$ thin film (synthesized at room temperature) annealed at $350{ }^{\circ} \mathrm{C}$ for $1 \mathrm{~h}$ under $\mathrm{N}_{2}$. 
Figure 3 indicates the Raman spectra of $\mathrm{Sb}_{2} \mathrm{~S}_{3}$ thin film annealed at $350{ }^{\circ} \mathrm{C}$ for $1 \mathrm{~h}$ under $\mathrm{N}_{2}$. Two peaks at $115 \mathrm{~cm}^{-1}$ and $150 \mathrm{~cm}^{-1}$ were observed in the Raman spectra.

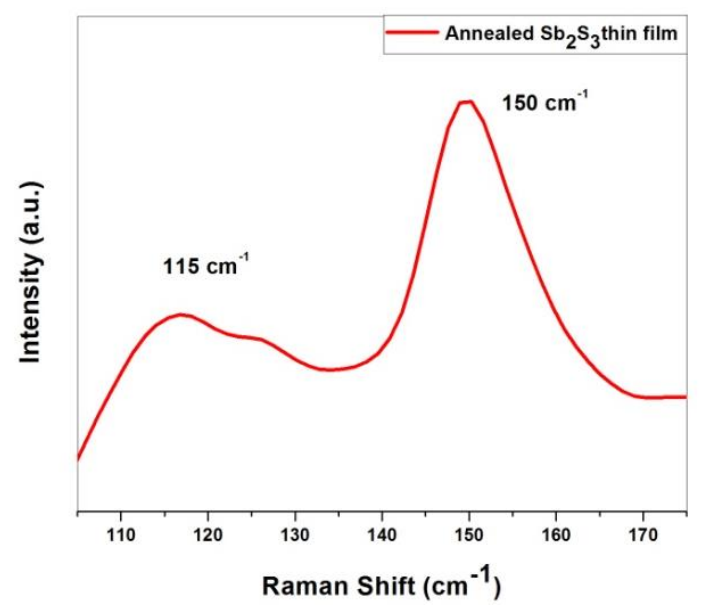

Figure 3. Raman spectra of $\mathrm{Sb}_{2} \mathrm{~S}_{3}$ thin film annealed at $350{ }^{\circ} \mathrm{C}$ for $1 \mathrm{~h}$ under $\mathrm{N}_{2}$.

This result is consistent with result obtained by Watanable et al. [20] who explained that the maximum band at $150 \mathrm{~cm}^{-1}$ can be assigned to the vibration $\mathrm{Sb}-\mathrm{Sb}$ bonds in $\mathrm{S}_{2} \mathrm{Sb}-\mathrm{SbS}_{2}$ structural units whereas the band at $115 \mathrm{~cm}^{-1}$ can be associated with the vibration modes of $\mathrm{SbS}_{3}$ pyramids, which are main building units of the film. The reason of the sharp intensity of the band at $150 \mathrm{~cm}^{-1}$ could be due to the increase in grain size of the $\mathrm{Sb}_{2} \mathrm{~S}_{3}$ thin film annealed at $350{ }^{\circ} \mathrm{C}$ for 1 $\mathrm{h}$ under $\mathrm{N}_{2}$. Minceva-Sukarova et al. [21] reported that the degree of sharpness reveals the crystalline nature of the $\mathrm{Sb}_{2} \mathrm{~S}_{3}$ thin film after annealing treatment which is in a good agreement with our XRD result.

The band structures of as- deposited and annealed $\mathrm{Sb}_{2} \mathrm{~S}_{3}$ thin films prepared by chemical bath deposition method at room temperature were studied using UV-Vis spectroscopy. The aim of the optical studies of the thin films in this study is to make comparison between as- deposited and annealed $\mathrm{Sb}_{2} \mathrm{~S}_{3}$ thin films and to show how band gap of the $\mathrm{Sb}_{2} \mathrm{~S}_{3}$ thin film changes after it was annealed at $350{ }^{\circ} \mathrm{C}$ for $1 \mathrm{~h}$ under $\mathrm{N}_{2}$. The optical absorption spectra of as-deposited and annealed $\mathrm{Sb}_{2} \mathrm{~S}_{3}$ thin films prepared at room temperature is shown in Figure 4.

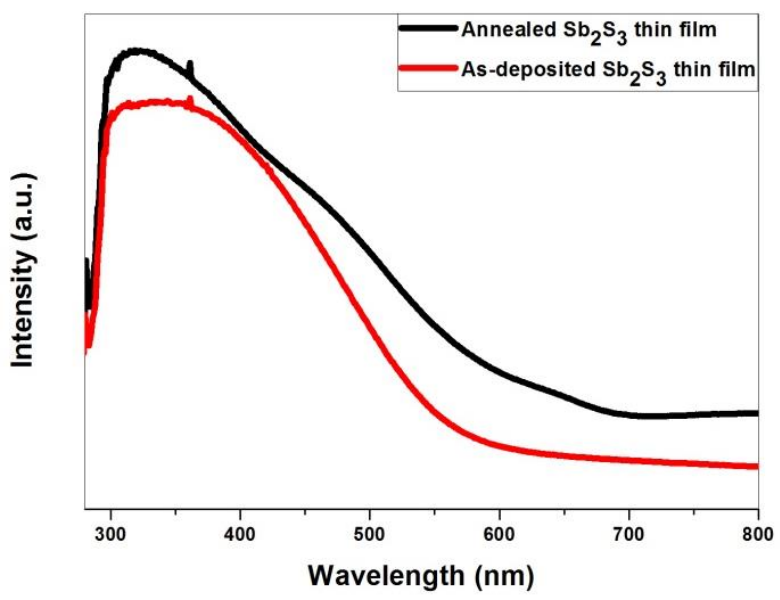

Figure 4. The UV-visible absorption spectra of as- deposited $\mathrm{Sb}_{2} \mathrm{~S}_{3}$ and annealed $\mathrm{Sb}_{2} \mathrm{~S}_{3}$ thin films.

Based on optical absorption spectra shown in Figure 4, two effects of annealing were observed on the optical properties. The first of them is that the absorption edge $(\sim 700 \mathrm{~nm})$ of the $\mathrm{Sb}_{2} \mathrm{~S}_{3}$ thin film annealed at $350{ }^{\circ} \mathrm{C}$ for $1 \mathrm{~h}$ under $\mathrm{N}_{2}$ is red shifted compare to as- deposited $\mathrm{Sb}_{2} \mathrm{~S}_{3}$ thin film $(\sim 579 \mathrm{~nm})$. Owing to annealing treatment, the increase in the grain size causes the red shifted. The calculation of the band gap for as-deposited and annealed $\mathrm{Sb}_{2} \mathrm{~S}_{3}$ thin films deposited onto glass substrates by chemical bath deposition at room temperature was done by using the relation is given in Equation 2.

$$
\alpha h v=\mathrm{C}\left(\mathrm{h} v-\mathrm{E}_{\mathrm{g}}\right)^{1 / 2}
$$

where $\alpha$ is absoprtion coefficient, hv is photon energy, and $\mathrm{E}_{\mathrm{g}}$ is energy gap. The $(\alpha h v)^{2}$ versus hv for as-deposited and annealed $\mathrm{Sb}_{2} \mathrm{~S}_{3}$ thin films, is shown in Figure 5, were plotted using the data obtained from Figure 4, 


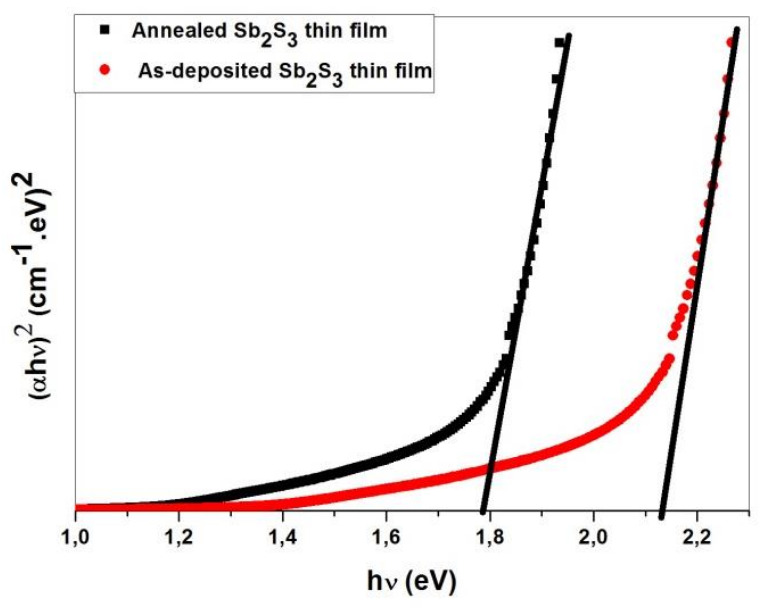

Figure 5. Determination of the optical band gap for asdeposited and annealed $\mathrm{Sb}_{2} \mathrm{~S}_{3}$ thin films using $(\alpha h v)^{2}$ vs hv plot.

Using above plot, it was found that the band gap of annealed $\mathrm{Sb}_{2} \mathrm{~S}_{3}$ thin films prepared at room temperature is around $1.77 \mathrm{e} \mathrm{V}(\sim 700 \mathrm{~nm})$ while the band gap of as- deposited $\mathrm{Sb}_{2} \mathrm{~S}_{3}$ thin films prepared at room temperature is around $2.14 \mathrm{e} \mathrm{V}(\sim 579 \mathrm{~nm})$. It can be clearly seen that the band gap of annealed $\mathrm{Sb}_{2} \mathrm{~S}_{3}$ thin film decreases after annealing treatment. Another effect of the annealing is to enhance the absorption spectral response of $\mathrm{Sb}_{2} \mathrm{~S}_{3}$ thin film. So that annealed $\mathrm{Sb}_{2} \mathrm{~S}_{3}$ thin film will have wide absorption windows. Because of this effect, it can be said that annealed $\mathrm{Sb}_{2} \mathrm{~S}_{3}$ thin films prepared by chemical bath deposition at room temperature can be used effectively as sensitizers in solar cell technologies.
Figure 6 indicates the current density $(\mathrm{J})$ versus voltage $(\mathrm{V})$ of the as deposited and annealed $\mathrm{Sb}_{2} \mathrm{~S}_{3}$ semiconductor-sensitized solar cells which prepared at room temperature, examined under 100 $\mathrm{mW} / \mathrm{cm}^{2}$ light intensity.

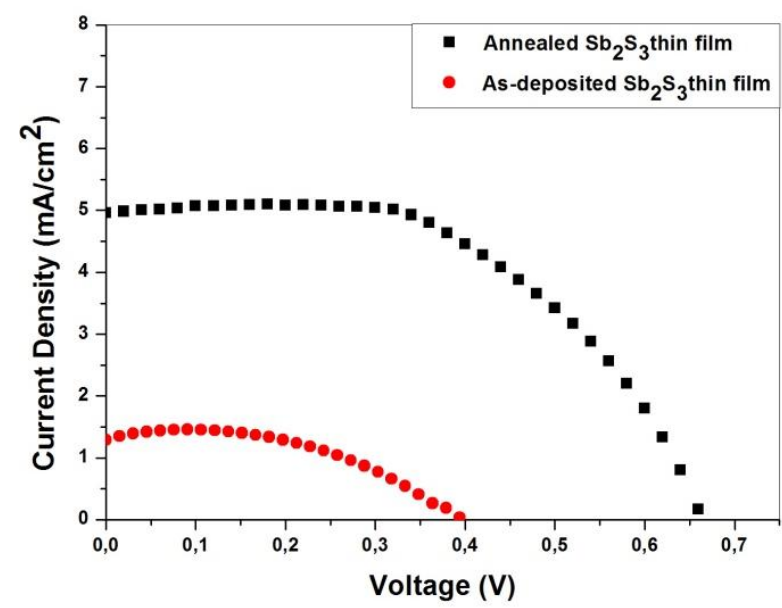

Figure 6. $\mathrm{J}-\mathrm{V}$ plots of as-deposited and annealed $\mathrm{Sb}_{2} \mathrm{~S}_{3}$ semiconductor-sensitized solar cell synthesized at room temperature.

It is important to note that there is a significant improvement in the performance of the annealed $\mathrm{Sb}_{2} \mathrm{~S}_{3} \quad$ semiconductor-sensitized solar cells prepared at room temperature compare to asdeposited $\mathrm{Sb}_{2} \mathrm{~S}_{3}$ semiconductor-sensitized solar cell. The power conversion efficiencies (shown in Table 2) were found $1,78 \%$ and $0,24 \%$ for annealed and as-deposited $\mathrm{Sb}_{2} \mathrm{~S}_{3}$ thin films prepared at room temperature, respectively.

Table 2. Comparison of $\mathrm{V}_{\mathrm{OC}}, \mathrm{J}_{\mathrm{SC}}$, and $\eta$ of annealed and as-deposited $\mathrm{Sb}_{2} \mathrm{~S}_{3}$ semiconductor-sensitized solar cells prepared at room temperature.

\begin{tabular}{cccc}
\hline Samples & $\begin{array}{c}\text { Open circuit } \\
\text { voltage }\left(\mathbf{V}_{\mathbf{O C}}\right)(\mathbf{V})\end{array}$ & $\begin{array}{c}\text { Short circuit current } \\
\text { density }(\mathbf{J} \mathbf{s c})\left(\mathbf{m A} / \mathbf{c m}^{2}\right)\end{array}$ & $\begin{array}{c}\text { Power conversion } \\
\text { efficiency }(\boldsymbol{\eta} \%)\end{array}$ \\
\hline $\begin{array}{c}\text { Annealed } \mathrm{Sb}_{2} \mathrm{~S}_{3} \\
\text { (room temperature) }\end{array}$ & 0,66 & 4,83 & 1,78 \\
$\begin{array}{c}\text { As-deposited } \mathrm{Sb}_{2} \mathrm{~S}_{3} \\
\text { (room temperature) }\end{array}$ & 0,4 & 1,3 & 0,24 \\
\hline
\end{tabular}

The reasons of this improvement could be arrayed [16];

The annealed $\mathrm{Sb}_{2} \mathrm{~S}_{3}$ thin film has the enhanced spectral response compare to as-deposited films (shown in Figure 4). This enhancement will improve the current density. (2) The grain size of the $\mathrm{Sb}_{2} \mathrm{~S}_{3}$ thin film increases after annealing process (shown in Figure 1). The increment in the grain size will reduce the particle to particle 
hopping of the photo-induced carrier. (3) Annealed $\mathrm{Sb}_{2} \mathrm{~S}_{3}$ thin film has a high crystal quality (shown in Figure 1). The improvement in the crystalline will reduce the recombination of photo-excited carriers and this effect will increase the power conversion efficiency. (4) One of the important factors to enhance the efficiency is the contact between working electrodes and nano-structured semiconductor sensitizers. The contact between $\mathrm{Sb}_{2} \mathrm{~S}_{3}$ thin film and $\mathrm{TiO}_{2} \mathrm{NW}$ becomes good due to annealing effect. This good contact can block the interfacial recombination of the injected transfer from NWs to polysulfide electrolytes. Correspondingly, it will improve the performance of the annealed $\mathrm{Sb}_{2} \mathrm{~S}_{3}$ semiconductor-sensitized solar cells.

\section{CONCLUSIONS}

In this study, we report the structural, optical and photovoltaic properties of as-deposited and annealed $\mathrm{Sb}_{2} \mathrm{~S}_{3}$ thin films prepared by chemical bath deposition at room temperature. Desired $\mathrm{Sb}_{2} \mathrm{~S}_{3}$ thin films prepared at room temperature were successfully obtained when the thin film was annealed at $350{ }^{\circ} \mathrm{Cfor} 1 \mathrm{~h}$ under $\mathrm{N}_{2}$. As deposited $\mathrm{Sb}_{2} \mathrm{~S}_{3}$ thin film showed amorphous structures while the $\mathrm{Sb}_{2} \mathrm{~S}_{3}$ thin film became polycrystalline after annealing at $350{ }^{\circ} \mathrm{C}$ for $1 \mathrm{~h}$ under $\mathrm{N}_{2}$. The band gaps of the $\mathrm{Sb}_{2} \mathrm{~S}_{3}$ thin films were compared using UVVis spectroscopy. The spectral response of the $\mathrm{Sb}_{2} \mathrm{~S}_{3}$ thin film enhanced after annealing process. Based on the optical and photovoltaic measurements, we consider that annealed $\mathrm{Sb}_{2} \mathrm{~S}_{3}$ thin films can be promising materials for developing solar cell technologies.

\section{REFERENCES}

[1]. M T S Nair, J. Electrochem. Sec. 145, 2113(1998)

[2]. S Mahanty, J. Vac. Sci. Tech. A Vac Surf Films15, 3060 (1997)

[3]. M D Jeroh, Global Journal of Science Frontier Research A 12, 1 (2012)

[4]. I Grozdanov, Semicond. Sci. Technol. 9, 1234 (1994)

[5]. M. Versal, Thin Solid Films 515, 7171 (2007)

[6]. S V Forgue, RCA Rev.12 335 (1951)

[7]. C Ghash, Thin Solid Films 60, 61 (1979)

[8]. J Grigas, Phys. Status Solidi (a) 37 K39 (1976)

[9]. E Montrimas, Thin Solid Films 34, 65 (1976)

[10]. J George, Solid States Commun. 33, 987 (1980)

[11]. P Arun, J. Materials Sci.31, 6507 (1996)

[12]. P E Lippens, Physical Review B, 5613054 (1997)

[13]. A Kyono, Phys Chem Minerals 29, 254 (2002)

[14]. F I Ezeme, Turk j. Phys 31, 205 (2007)

[15]. B Krishnan, Applied Surface Science 254, 3200 ( 2008)

[16]. Y Li, Nanoscale Research Letters 8, 89 (2013)

[17]. C G Lazos, Journal of the Electrochemical Society $155,158(2008)$

[18]. Q Dai, Nano Letters 12, 1021 (2012)

[19]. J Pan, Eur. J. Inorg. Chem. 5302 (2009)

[20]. I Watanabe, Journal of Non-Crystalline Solids 58, 35 (1983)

[21]. B Minceva-Sukarova, Journal of Molecular Structure 410-411, 267 (1997) 